\title{
Mixotrophic Cultivation of Microalgae in Cassava Processing Wastewater for Simultaneous Treatment and Production of Lipid-Rich Biomass
}

\author{
Vanessa Ghiggi Sorgatto, Carlos Ricardo Soccol, Denisse Tatiana Molina-Aulestia, Marco Aurélio de Carvalho (D, \\ Gilberto Vinícius de Melo Pereira and Júlio Cesar de Carvalho *(D)
}

\section{check for} updates

Citation: Sorgatto, V.G.; Soccol, C.R.; Molina-Aulestia, D.T.; de Carvalho, M.A.; de Melo Pereira, G.V.; de Carvalho, J.C. Mixotrophic Cultivation of Microalgae in Cassava Processing Wastewater for Simultaneous Treatment and Production of Lipid-Rich Biomass. Fuels 2021, 2, 521-532. https:// doi.org/10.3390/fuels2040030

Academic Editor: Mamoru Yamada

Received: 21 October 2021

Accepted: 25 November 2021

Published: 1 December 2021

Publisher's Note: MDPI stays neutra with regard to jurisdictional claims in published maps and institutional affiliations.

Copyright: (c) 2021 by the authors. Licensee MDPI, Basel, Switzerland. This article is an open access article distributed under the terms and conditions of the Creative Commons Attribution (CC BY) license (https:// creativecommons.org/licenses/by/ $4.0 /)$.
Bioprocess Engineering and Biotechnology Department, Federal University of Parana (UFPR), Curitiba 81531-990, Brazil; vanessaghiggi3@gmail.com (V.G.S.); soccol@ufpr.br (C.R.S.); denisse.molina@ufpr.br (D.T.M.-A.); marcoaurelio@utfpr.edu.br (M.A.d.C.); gilbertovinicius@ufpr.br (G.V.d.M.P.) * Correspondence: jccarvalho@ufpr.br

\begin{abstract}
Cassava processing wastewater (CPW) is a highly polluting, liquid residue of cassava processing, usually discarded or treated anaerobically. However, it can serve as a low-cost culture medium for microalgae. After a preliminary evaluation of the growth of 10 microalgal strains in diluted CPW, the microalgae Haematococcus pluvialis SAG 34-1b and Neochloris (Ettlia) oleoabundans UTEX 1185 were selected for cultivation in CPW without a supply of additional nutrients and evaluated for their growth, lipid production, and nutrients removal. Maximal biomass concentrations of $1.79 \mathrm{~g} \cdot \mathrm{L}^{-1}$ for H. pluvialis and $3.18 \mathrm{~g} \cdot \mathrm{L}^{-1}$ for $\mathrm{N}$. oleoabundans were achieved with $25 \% \mathrm{CPW}$ medium on the 13th day of growth. The algae H. pluvialis and N. oleoabundans removed 60.80 and $69.16 \%$ of the chemical oxygen demand, 51.06 and $58.19 \%$ of total nitrate, and 54.68 and $69.84 \%$ of phosphate, respectively. On average, lipid productivities reached 0.018 and $0.041 \mathrm{~g} \cdot \mathrm{L}^{-1}$ day $^{-1}$ for $\mathrm{H}$. pluvialis and $N$. oleoabundans, respectively. Therefore, cultivating these microalgae in diluted CPW is a promising treatment for cassava wastewater with simultaneous valuable biomass production.
\end{abstract}

Keywords: Haematococcus pluvialis; Neochloris oleoabundans; manipueira; biodiesel; lipid; cassava; wastewater treatment

\section{Introduction}

Microalgal biomass can be used for many applications, from feed to biofuels [1-3], but its large-scale production requires large amounts of water and nutrients [4]. On the other side, there is a growing effort in the biotechnological valorization of agro-industry residues [5,6]. The use of agro-industrial residues in bioprocesses provides many new possibilities of nutrient-rich substrates while reducing pollution problems [7].

Cassava (Manihot esculenta L.) is a root cultivated in more than 100 countries, with an annual production of around 300 million tons (2018-2019), making it the 5th most important staple crop in the world, ahead of barley, sweet potatoes, and apples [8,9]. The top 10 producer countries are in Africa, Asia, and South America, and cassava is used for direct human consumption and processed into starch products.

Cassava processing wastewater (CPW) is a carbohydrate-rich residue generated in large amounts during cassava flour and starch production. It has been estimated that the volume of cassava wastewater generated by beneficiation of 1 ton of roots ranges from 300 to $3000 \mathrm{~L}[8,10,11]$ due to different dilutions during processing.

This residue from the cassava industry is considered a "harmful" pollutant waste due to its high organic content and the presence of cyanide $[8,12]$. However, from the biotechnological point of view, it can be considered a substrate rich in nutrients, which is suitable for several bioprocesses, including microalgae production (Table 1). 
Table 1. Microbial strains cultivated on cassava wastewater for various bioprocesses, the microalgae are presented in bold text.

\begin{tabular}{ccc}
\hline Microorganism & Products & References \\
\hline Rhodospirillum rubrum & Biohydrogen & {$[13]$} \\
Fusarium oxysporum & R-(+)- $\alpha$-terpineol & {$[14]$} \\
Pseudomonas aeruginosa & Rhamnolipid surfactants & {$[15]$} \\
Clostridium acetobutylicum & Biohydrogen & {$[16]$} \\
Mixed bacteria & Biohydrogen & {$[17]$} \\
Chlorella minutissima & Biomass, proteins and lipids, effluent treatment & {$[8]$} \\
Chlorella minutissima & Biomass, bioremediation & {$[18]$} \\
Phormidium autumnale & Biomass, lipids & {$[3]$} \\
Haematococcus pluvialis & Astaxanthin & {$[19]$} \\
Desmodesmus armatus & Biomass, bioremediation & {$[20]$} \\
Arthrospira platensis & Biomass, nutrient removal & {$[21]$} \\
\hline
\end{tabular}

Water and nutrient requirements are bottlenecks of large-scale microalgal cultivation. Several researchers have explored microalgae cultivation combined with wastewater treatment $[6,22,23]$ due to the microalgal capacity of removing pollutants, while growing heteroor mixotrophically and producing potentially valuable biomass. The use of residues can contribute to sustainable economic growth, both due to the circularity in nutrient recovery and the fixation of $\mathrm{CO}_{2}[4,24,25]$. Since CPW contains many nutrients, it is inherently lowcost and preliminarily shown to support the growth of microalgae. In addition, CPW-based media could be used to reduce the cost of algae-based bioproducts.

Few literature reports describe specifically the use of CPW (see Table 1), and two describe the use of glucose from hydrolyzed cassava [26-28] - a process that could be coupled with the use of CPW evaluated in this paper. In particular, the starch-degrading capability was observed in Phormidium autumnale [29] and green microalgae [8].

However, the residue's high COD and mild toxicity make microalgae production contingent to strain selection and adaptation. Therefore, the main goal of this study was to investigate growth and lipid production by two industrially important microalgal strains, Haematococcus pluvialis and Neochloris oleoabundans $[30,31]$ selected for cultivation in CPW after a preliminary screening to verify their potential for combining the wastewater treatment with algae culturing and biodiesel production. To our knowledge, it is the first report that successfully used CPW diluted solely in water, without nutrient amendment, to cultivate these microalgae.

\section{Materials and Methods}

\subsection{Microorganisms}

Preliminary evaluation of microalgal strains was conducted to identify strains tolerant to $10 \%$ CPW-based media (Table 2). According to the results of biomass productivity, all of the species evaluated are capable of growing at about $0.11 \mathrm{~g} \cdot \mathrm{L}^{-1}$ day $^{-1}$, and two accumulated more than $15 \%$ lipids. These two freshwater microalgae were selected, one due to its astaxanthin production capacity, Haematococcus pluvialis SAG 34-1b (purchased from SAG-Sammlung von Algenkulturen der Universität Göttingen-Göttingen, Germany) and one due to its higher biomass productivity (Neochloris oleoabundans UTEX 1185, purchased from the culture collections UTEX at University of Texas-Austin, TX, USA). The possibility of co-producing astaxanthin may be advantageous in a biorefinery process. 
Table 2. Biomass productivities of 10 microalgae cultivated in diluted cassava wastewater (10\%). The lipid content is estimated from the $\mathrm{C} / \mathrm{N}$ mass ratio.

\begin{tabular}{cc}
\hline Microalgae & Average Biomass Productivity $\left(\mathbf{g} \cdot \mathbf{L}^{-\mathbf{1} \cdot \mathbf{d a y}} \mathbf{B a}^{\mathbf{1}}\right)$ \\
\hline Amphiprora paludosa SAG 15.83 & $0.18 \pm 0.04$ \\
Aphanothece clathrata SAG 23.99 & $0.13 \pm 0.02$ \\
Botryococcus braunii SAG 30.81 & $0.15 \pm 0.05$ \\
Chlorella protothecoides SAG 211-7b & $0.09 \pm 0.02$ \\
Chlorella vulgaris SAG 2.80 & $0.10 \pm 0.04$ \\
Chlorococcum oleofaciens SAG 213-11 & $0.06 \pm 0.04$ \\
Dunaliella parva SAG 19-1 & $0.08 \pm 0.03$ \\
Haematococcus pluvialis SAG 34-1b & $0.08 \pm 0.02$ \\
Neochloris oleoabundans UTEX 1 185 & $0.21 \pm 0.03$ \\
Scenedesmus obliquus SAG 276-10 & $0.08 \pm 0.04$ \\
\hline
\end{tabular}

\subsection{Cassava Wastewater}

Cassava processing wastewater obtained from the manufacturing of cassava flour (Podium Alimentos Ltd., Paranavaí, Brazil) was collected, filtered through a qualitative filter of $11 \mu \mathrm{m}$ pore-size (Whatman Ltd., Maidstone, UK) to remove large solid particles before use, and stored at $-18 \pm 1{ }^{\circ} \mathrm{C}$ until needed. A wastewater sample was analyzed in the laboratory for its overall composition (Table 3) following standard methods [32]. The natural $\mathrm{pH}$ of $\mathrm{CPW}$ was not adjusted. The same cassava wastewater was used for all of the experiments.

Table 3. Composition of CPW used in this work.

\begin{tabular}{ccc}
\hline Components & Raw CPW & Sterilized CPW \\
\hline $\mathrm{pH}$ & $5.4 \pm 0.02$ & $5.4 \pm 0.02$ \\
Total solids $\left(\mathrm{g} \cdot \mathrm{L}^{-1}\right)$ & $38.5 \pm 0.13$ & $39.1 \pm 0.11$ \\
Volatile solids $\left(\mathrm{g} \cdot \mathrm{L}^{-1}\right)$ & $32.0 \pm 0.08$ & $32.7 \pm 0.08$ \\
Total carbohydrates $\left(\mathrm{g} \cdot \mathrm{L}^{-1}\right)$ & $39.5 \pm 1.10$ & $40.1 \pm 1.04$ \\
Reducing sugars $\left(\mathrm{g} \cdot \mathrm{L}^{-1}\right)$ & $15.3 \pm 0.30$ & $15.8 \pm 0.46$ \\
Total nitrate $\left(\mathrm{g} \cdot \mathrm{L}^{-1}\right)$ & $1.90 \pm 0.05$ & $1.92 \pm 0.04$ \\
Total phosphate $\left(\mathrm{mg} \cdot \mathrm{L}^{-1}\right)$ & $246 \pm 1.23$ & $258 \pm 1.41$ \\
Potassium $\left(\mathrm{g} \cdot \mathrm{L}^{-1}\right)$ & $2.02 \pm 0.03$ & $2.09 \pm 0.07$ \\
Magnesium $\left(\mathrm{mg} \cdot \mathrm{L}^{-1}\right)$ & $165 \pm 0.02$ & $164 \pm 0.02$ \\
COD $\left(\mathrm{g} \cdot \mathrm{L}^{-1}\right)$ & $46.8 \pm 0.26$ & $46.8 \pm 0.29$ \\
BOD $\left(\mathrm{g} \cdot \mathrm{L}^{-1}\right)$ & $16.7 \pm 0.12$ & $16.9 \pm 0.10$ \\
\hline
\end{tabular}

\subsection{Cultivation Conditions}

To determine the suitable CPW concentration for microalgae growth, an inoculum of each microalga was prepared in a modified ES Basal Medium containing (per liter): $0.2 \mathrm{~g} \mathrm{KNO}_{3}, 0.02 \mathrm{~g} \mathrm{~K}_{2} \mathrm{HPO}_{4}, 0.02 \mathrm{~g} \mathrm{MgSO}_{4} \cdot 7 \mathrm{H}_{2} \mathrm{O}$, and $0.005 \mathrm{~L}$ micronutrient stock solution $\left(77 \mu \mathrm{M} \mathrm{ZnSO} \cdot 7 \mathrm{H}_{2} \mathrm{O} ; 18 \mu \mathrm{M} \mathrm{MnCl}_{2} \cdot 4 \mathrm{H}_{2} \mathrm{O} ; 462 \mu \mathrm{M} \mathrm{H}_{3} \mathrm{BO}_{3} ; 4.2 \mu \mathrm{M} \mathrm{Co}\left(\mathrm{NO}_{3}\right)_{2} \cdot 6 \mathrm{H}_{2} 0\right.$; $12 \mu \mathrm{M} \mathrm{Na}_{2} \mathrm{MoO}_{4} \cdot 2 \mathrm{H}_{2} \mathrm{O} ; 16 \mu \mathrm{M} \mathrm{CuSO}_{4} \cdot 5 \mathrm{H}_{2} \mathrm{O} ; 45 \mu \mathrm{M} \mathrm{FeSO}_{4} \cdot 7 \mathrm{H}_{2} \mathrm{O} ; 428 \mu \mathrm{M} \mathrm{Na}_{2}$ EDTA). After cultivation, inocula were transferred to $2 \mathrm{~L}$ Erlenmeyer flasks containing $1 \mathrm{~L}$ of medium with different concentrations $(25,50,75$, and $100 \%)$ of $\mathrm{CPW}$, and the culture was monitored for 15 days.

The most favorable concentration (25\%) of CPW for algal growth was taken for comparison with a synthetic mixotrophic medium. Cultures suspension of $H$. pluvialis and $N$. oleoabundans were used to inoculate each flask. The strains were grown in $2 \mathrm{~L}$ Erlenmeyer flasks with $1 \mathrm{~L}$ of synthetic mixotrophic medium (ES Basal Medium supplemented with $10 \mathrm{~g} \cdot \mathrm{L}^{-1}$ of glucose) and $2 \mathrm{~L}$ Erlenmeyer flasks containing $1 \mathrm{~L}$ of medium with $25 \%$ of filtered CPW.

All of the media were sterilized at $1 \mathrm{~atm}, 121{ }^{\circ} \mathrm{C}$ for $15 \mathrm{~min}$, and inoculated with $10 \%(v / v)$ of homogeneous algal suspension. The cultures were maintained for 15 days at 
$25 \pm 1{ }^{\circ} \mathrm{C}$, with occasional manual shaking, and lighted with cool fluorescent lights under light:dark cycle of $12 \mathrm{~h}$ at an irradiance of $48 \mu \mathrm{mol}$ photons $\mathrm{m}^{-2} \mathrm{~s}^{-1}$.

\subsection{Analytical Methods}

\subsubsection{Determination of Cell Concentration}

The biomass concentration was determined gravimetrically by collecting $5 \mathrm{~mL}$ of microalgae suspension, centrifugation at $5000 \mathrm{rpm}, 5^{\circ} \mathrm{C}$ for $10 \mathrm{~min}$ (Sorvall Legend Mach 1.6R), and drying the pellet to constant weight at $45^{\circ} \mathrm{C}$ in a vacuum drying cabinet. Samples without algae were used as blank.

\subsubsection{Characterization of Cassava Processing Wastewater}

The wastewater quality parameters were analyzed in the raw and sterilized wastewater by the standard methods described below. To evaluate the potential of pollutant reduction, after finishing cultivation (15th day of microalgae culture), the incubation was stopped, and the total culture medium volume was centrifuged at $5000 \mathrm{rpm}, 5^{\circ} \mathrm{C}$ for $10 \mathrm{~min}$. The cell pellets were collected and processed for lipid analyses, while the supernatants were analyzed to determine the parameters COD, BOD, total nitrate, and total phosphate according to the standard methods for the examination of water and wastewater [32].

Removal ratios (\%) for those nutrients were calculated by dividing the difference between the first day and the last day concentrations by the first day concentration and then multiplied by 100 .

The $\mathrm{pH}$ value:The $\mathrm{pH}$ was measured using a $\mathrm{pH}$ meter (MS Tecnopon mPA2010).

Carbohydrates analyses: Total carbohydrates were estimated using the colorimetric method based on the Phenol-sulfuric assay [33]. Measurements of reducing sugars were estimated according to [34].

Total Phosphate and Nitrate contents were determined according to the procedures SM 4500-P E and SM 4500-NO3 B, respectively, used in standard methods [32].

Total Potassium and Magnesium were determined according to the procedure SM 3120 B [32].

Chemical Oxygen Demand (COD) was determined using the Closed Reflux Colorimetric Method in accordance with the procedure SM 5220 D [32].

Biochemical Oxygen Demand (BOD) was determined using the manometric method in accordance with the procedure SM5210 B [32].

Total and Volatile Solids were analyzed by gravimetric analysis, according to Method 1684 described by the US Environmental Protection Agency's (EPA's) Office of Water [35].

\subsubsection{Lipid Analysis}

The wet paste collected by centrifugation was dried at $45^{\circ} \mathrm{C}$ for $24 \mathrm{~h}$ under a vacuum oven and grounded in a mortar. The lipids were extracted using a gravimetric method adapted from Folch [36]. Approximately $1 \mathrm{~g}$ of dry biomass settled in a cellulose cartridge was immersed in a $100 \mathrm{~mL}$ mixture of chloroform:methanol $(2: 1, v / v)$ in a Soxhlet apparatus for $4 \mathrm{~h}$ with reflux at $53^{\circ} \mathrm{C}$. At the end of extraction, the extracting solvent was distilled to recycle the chloroform:methanol mixture followed by drying the lipid fraction at $45^{\circ} \mathrm{C}$ under a vacuum for $6 \mathrm{~h}$ and weighing after cooling to room temperature. The lipid content was calculated by dividing the residue weight by the DCW.

\subsubsection{FAME Analysis by Gas Chromatography}

Fatty acids were methylated by the direct transesterification method described by Liu and Zhao [37], with reaction conditions of $70{ }^{\circ} \mathrm{C}$, under ambient pressure for $20 \mathrm{~h}$, and biomass:methanol ratio 1:20 (w/v) catalyzed by $0.2 \mathrm{~mol} \cdot \mathrm{L}^{-1} \mathrm{H}_{2} \mathrm{SO}_{4}$.

The FAME was analyzed by gas chromatography using a Shimadzu GC 2010 instrument equipped with a Restek RTX-Wax column and a flame ionization detector. Operating conditions were as follows: Injector temperature $250^{\circ} \mathrm{C}$; oven temperature initially $130^{\circ} \mathrm{C}$, holding $2 \mathrm{~min}$, then heating to $230{ }^{\circ} \mathrm{C}$ at $15^{\circ} \mathrm{C} \mathrm{min}^{-1}$; holding for $8 \mathrm{~min}$; finally, heating to 
$240{ }^{\circ} \mathrm{C}$ at $20^{\circ} \mathrm{C} \mathrm{min}-1$, then holding for $2 \mathrm{~min}$. The detector temperature was $250{ }^{\circ} \mathrm{C}$. Fatty acids were identified by comparing their retention times and areas with a mixed fatty acid methyl ester standard (Supelco 37 FAME mix).

\subsubsection{Data Analysis}

The present results are the mean of the values obtained for each sample. The average values are reported. The differences in mean values $(n=3)$ as well as between the mean percentages $(n=3)$ were assessed with a simple statistical analysis using Microsoft Excel, by the analysis of variance ANOVA, and Student's $t$-test, and were statistically different at a significance level of $5 \%$.

\section{Results and Discussion}

\subsection{Microalgae Growth in $C P W$}

The growth kinetics of the selected strains for cultivation in CPW were evaluated at four concentrations $(25,50,75$, and $100 \%)$ and compared with a culture in the synthetic mixotrophic medium. Both microalgae are relatively tolerant to the cassava wastewater conditions. The better performance for the growth of both microalgae strains was at $25 \%$ diluted CPW medium (Figure 1), since the use of high concentrations of CPW (50, 75, and $100 \%$ ) resulted in significantly less biomass, although the cells remained viable.

(a)

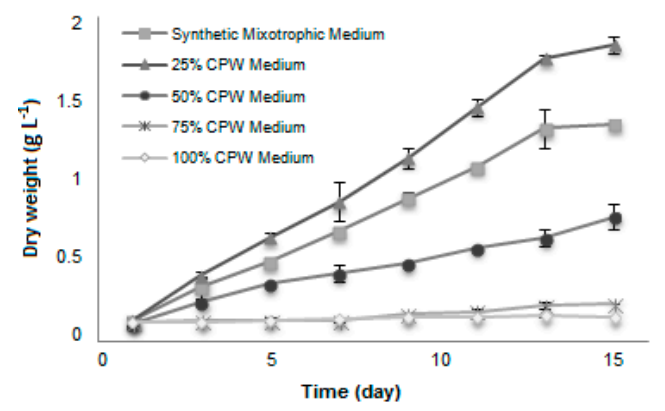

(b)

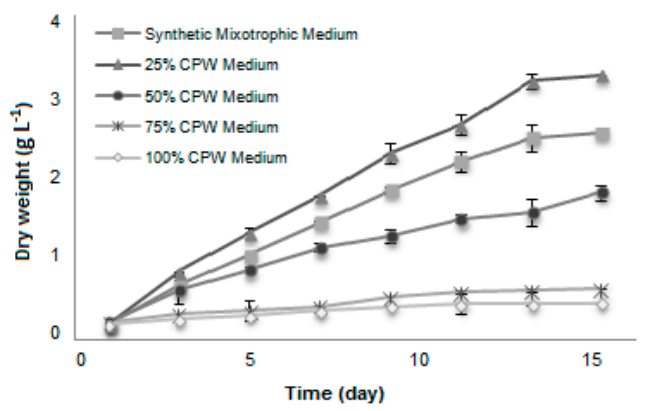

Figure 1. Dry cell weight of microalgae in a synthetic mixotrophic medium and different concentrations of CPW $(25,50,75$, and 100\%): (a) H. pluvialis and (b) N. oleoabundans. Data are averages \pm standard error.

Various factors upon which algal growth depends may be responsible for the results: (1) Substrate inhibition where the low concentration of substrate stimulates cell growth, whereas the high concentration has an inhibitory effect; (2) the turbidity in the high concentrations of wastewater decreasing the light penetration and reducing the photosynthetic efficiency; (3) increase of osmolarity; or (4) toxic compounds remain present in the high concentrated CPW media.

The microalgae $H$. pluvialis and $N$. oleoabundans also showed better biomass growth and productivity in $25 \% \mathrm{CPW}$ compared with the synthetic mixotrophic medium (ES basal medium $+10 \%$ glucose), and no apparent lag phase was observed. In CPW-based media, the biomass concentration of $H$. pluvialis and $N$. oleoabundans reached a maximum of $1.79 \pm 0.03 \mathrm{~g}$ and $3.18 \pm 0.05 \mathrm{~g}$ of dry biomass per liter of culture, respectively on the 13th day of cultivation. The average specific growth rates observed were 0.24 and $0.29 \mathrm{~d}^{-1}$ for $H$. pluvialis and N. oleoabundans, respectively. In comparison, in the synthetic mixotrophic medium, the microalgae reached maximal cellular concentrations of $1.30 \pm 0.10 \mathrm{~g}$ and $2.49 \pm 0.08 \mathrm{~g}$ of dry biomass per liter of culture and an average growth rate of 0.21 and $0.24 \mathrm{~d}^{-1}$, respectively, indicating that both microalgae have a satisfactory growth in CPW medium, comparable with the previously reported literature for these microalgae $[31,38,39]$. Other species cultivated in CPW presented a comparable biomass production: $0.85 \mathrm{~g} \cdot \mathrm{L}^{-1}$ in 12 days (or a productivity of $0.071 \mathrm{~g} \cdot \mathrm{L}^{-1} \cdot \mathrm{d}^{-1}$ ) for Desmodesmus armatus in Bold's Basal Medium-enriched CPW [20], $0.936 \mathrm{~g} \cdot \mathrm{L}^{-1}$ in 7 days (or a productivity of $0.124 \mathrm{~g} \cdot \mathrm{L}^{-1} \cdot \mathrm{d}^{-1}$ ) for Chlorella minutissima in 1\% CPW [18], (nutrient addition, perhaps carried from the $15 \%$ 
inoculum volume, is not disclosed). The biomass production was lower than observed in heterotrophic batch production of Phormidium autumnale in CPW added of $\mathrm{NH}_{4} \mathrm{NO}_{3}$ [3], which reached $5.2 \mathrm{~g} / \mathrm{L}$ in 5 days (or a productivity of $1.02 \mathrm{~g} \cdot \mathrm{L}^{-1} \cdot \mathrm{d}^{-1}$ ).

Figure 1 also clearly shows that the growth rate is inversely proportional to the CPW concentration in the range of concentrations tested. However, there is a limit to how much biomass can be produced from the diluted CPW since dilution implies that fewer nutrients are available. Assuming that with $0 \% \mathrm{CPW}$ (pure water), the net biomass growth would be zero, then the approximate final biomass concentration, $X_{f}$, after 13 days can be predicted by polynomial regression equations, Equations (1) and (2), in the range $0-50 \%$ CPW concentration:

$$
\begin{aligned}
& \text { H. pluvialis } \mathrm{X}_{\mathrm{f}}, \mathrm{g} \cdot \mathrm{L}^{-1}=0.1-22[\mathrm{CPW}]^{2}+12.2[\mathrm{CPW}] \\
& \text { N. oleoabundans } \mathrm{X}_{\mathrm{f}}, \mathrm{g} \cdot \mathrm{L}^{-1}=0.1-36[\mathrm{CPW}]^{2}+21.4[\mathrm{CPW}]
\end{aligned}
$$

These equations are only valid for the CPW batch used, probably varying with season and processing but conserving its parabolic shape. The equations allow one to ponder the biomass concentration, biomass production, and pond area for treating a given amount of CPW. In this analysis, it is essential to differentiate between CPW and biomass amounts and concentrations. The nutrients in a given amount of CPW can support a maximum amount of biomass irrespective of how much the residue will be diluted (the maximal biomass amount depends on the concentration of nitrogen, phosphate, microelements, and the species of alga). However, the CPW concentration affects the biomass growth rate, final concentration, and the production area-the concentrated CPW requires less land area than the diluted CPW. Figure 2 presents projected values for biomass concentration, pond area, total biomass production per batch, and areal productivity as a function of $\mathrm{CPW}$ concentration.
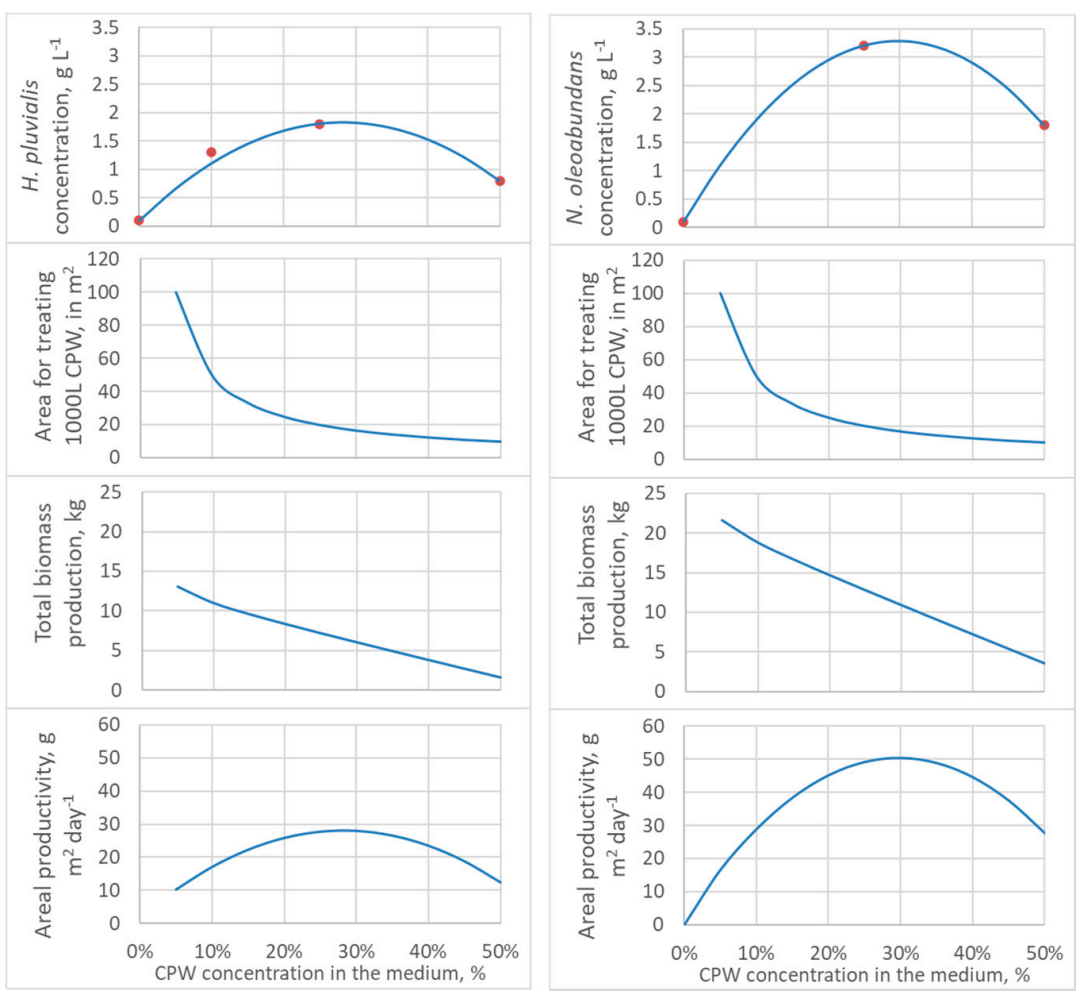

Figure 2. Model estimates as a function of CPW concentration (from 0 to $50 \%$ effluent): Dry cell weight, the area necessary for treating $1000 \mathrm{~L}$ of filtered CPW, total biomass production from $1000 \mathrm{~L}$ of filtered CPW, and productivity per pond area, considering high-rate ponds of $20 \mathrm{~cm}$ depth and 13 days of batch culture. Left curves, H. pluvialis; right curves, N. oleoabundans. Red dots are experimental values. 
In Figure 2, biomass concentration was estimated using Equations (1) and (2). The pond area for treating a volume of residue $\mathrm{V}_{\mathrm{CPW}}$, in liters, with a concentration [CPW], in percentage, and depth $\mathrm{h}$, in $\mathrm{cm}$, can be calculated by Equation (3):

$$
\text { Pond area, } \mathrm{m}^{2}=\left(\mathrm{V}_{\mathrm{CPW}} /[\mathrm{CPW}]\right) /(10 \mathrm{~h})
$$

The total biomass production is the product of biomass concentration and effective culture medium volume, given by Equation (4):

$$
\text { Total biomass production, } \mathrm{kg}=\mathrm{X}_{\mathrm{f}}\left(\mathrm{V}_{\mathrm{CPW}} /[\mathrm{CPW}]\right) / 1000
$$

And finally, the areal productivity is simply the quotient of total biomass by area and time or Equation (4) divided by Equation (3) and the batch duration in days, to give:

$$
\text { Areal biomass productivity, } \mathrm{kg} \mathrm{m}^{-2}=\mathrm{X}_{\mathrm{f}} \mathrm{h} /(100 \mathrm{t})
$$

In Figure 2, a calculation basis of $\mathrm{V}_{\mathrm{CPW}}=1000 \mathrm{~L}$, and ponds with $20 \mathrm{~cm}$ depth were considered. While the CPW concentration that gives the maximal biomass concentration and most intensive land use is about $20-30 \%$ for both microalgae (Figure 2), the maximum biomass production occurs with lower $\mathrm{CPW}$ concentrations. The maximal biomass concentration and minimal land use are best for economical processing, facilitating downstream, and managing due to the lower processing volumes, while aiming at maximum biomass production is interesting for biomasses with high added-value, as it would be the case for H. pluvialis after carotenogenesis induction.

However, while higher dilutions lead to higher biomass production, there must be a point where limiting nutrients becomes too diluted. For example, $1 \% \mathrm{CPW}$, with $19 \mathrm{mg} \cdot \mathrm{L}^{-1}$ of nitrate or $4.2 \mathrm{mg} \cdot \mathrm{L}^{-1}$ elemental nitrogen, could support the synthesis of only $27 \mathrm{mg} \cdot \mathrm{L}^{-1}$ of protein (considering protein $=6.25 \times \mathrm{N}$, an average conversion factor) [40], and therefore 38 to $67 \mathrm{mg} \cdot \mathrm{L}^{-1}$ of biomass with 40 to $70 \%$ protein, a content range typical for microalgae [41]. Therefore, optimization is necessary for each specific system (CPW composition and microalgal species).

\subsection{Characteristics of Cassava Wastewater}

The typical cassava wastewater is known as a complex mixture of natural organic and inorganic compounds with variable COD $[5,10,13]$, from 6 to $56 \mathrm{~g} \cdot \mathrm{L}^{-1}$ depending on the process [8]. The composition of CPW used in this study is presented in Table 3.

The CPW used in this experiment showed an average elemental N:P ratio of 12:1, not so far from the Redfield ratio of 16:1 as some typical culture media [4,42], explaining how $\mathrm{CPW}$ can support the growth of both freshwater microalgae without supplementation, at a concentration of $25 \%$. The C:N:P ratio is not meaningful since the microalgae can use both organic and inorganic $\left(\mathrm{CO}_{2}\right)$ carbon sources.

\subsection{Removal of Pollutants from CPW by Microalgae \\ 3.3.1. Nitrate and Phosphate Reduction}

One of the main requirements of wastewater treatment is the removal of nutrients as nitrogen and phosphorous, which otherwise can lead to risks of eutrophication if these nutrients accumulate in the aquatic environment [43]. The results concerning nitrate and phosphate removal from the CPW (Table 4) show a slight reduction of $3 \pm 0.29 \%$ by the filtration process for both components. At the same time, the H. pluvialis and N. oleoabundans cultivation presented a reduction of $51.06 \pm 3.01 \%$ and $58.19 \pm 2.56 \%$ in total nitrate content and $54.68 \pm 2.05 \%$ and $69.84 \pm 1.82 \%$ in total phosphate content, respectively. 
Table 4. Removal of nitrate and phosphate from the CPW after 15 days of cultivation.

\begin{tabular}{cccccc}
\hline Components & $\begin{array}{c}\text { Sterilized Raw } \\
\text { CPW }\end{array}$ & $\begin{array}{c}\text { Sterilized Filtered } \\
\text { CPW }\end{array}$ & 25\% Filtered CPW & $\begin{array}{c}\text { H. pluvialis } \\
\text { Culture }\end{array}$ & $\begin{array}{c}\text { N. oleoabundans } \\
\text { Culture }\end{array}$ \\
\hline Total nitrate $\left(\mathrm{g} \cdot \mathrm{L}^{-1}\right)$ & $1.92 \pm 0.04$ & $1.86 \pm 0.05$ & $0.47 \pm 0.01$ & $0.23 \pm 0.01$ & $0.20 \pm 0.01$ \\
Total phosphate $\left(\mathrm{mg} \cdot \mathrm{L}^{-1}\right)$ & $258 \pm 1.41$ & $250 \pm 1.37$ & $62.55 \pm 0.35$ & $28.10 \pm 1.27$ & $18.70 \pm 1.13$ \\
\hline
\end{tabular}

The present study provides evidence of efficient remediation by consumption of nitrogen and phosphorus by both microalgae without an adverse effect on the growth rate. A remarkable reduction in nitrogen and phosphorus contents was also reported in earlier studies, with the elimination of nitrogen ranging from 50.2 to $89.1 \%$ and phosphorus from 33.0 to $83.0 \%$, in industrial, domestic, and agricultural wastewaters, treated by different microalgae strains, such as Chlorella pyrenoidosa [44], Scenedesmus obliquus [22], and Chlamydomonas sp. [7].

Several factors have been reported to explain the incomplete nitrate and phosphate assimilation since algal growth and nutrient uptake are clearly not only affected by the availability of nutrients, but also depend on complex interactions among physical, chemical, and biotic factors $[1,45,46]$.

Considering the previously reported data of wastewater treatments, these results could be improved with the use of more concentrated cultures of algal biomass, since on a small scale, experiments with hyper-concentrated algal biomass $>1.5 \mathrm{~g} \cdot \mathrm{L}^{-1}$ cultures have shown that these can accelerate the removal of nutrients compared with typical cultures [23].

\subsubsection{Chemical and Biochemical Oxygen Demand Reduction}

The CPW presents a high value of COD and BOD, representing high environmental impact, but it was reduced to a lower value due to the absorption of organic compounds and production of oxygen by microalgae under mixotrophic growth. The pretreatment by filtration presented a reduction of $30.0 \pm 1.20 \%$ in COD and $14.7 \pm 0.83 \%$ in BOD content of $\mathrm{CPW}$, by the partial removal of suspended solids when the medium was prepared. This process increases the biodegradability of the residue by increasing the BOD/COD ratio (Table 5), a parameter of wastewater characterization [47].

Table 5. COD and BOD removal efficiency by H. pluvialis and N. oleoabundans cultures.

\begin{tabular}{cccccc}
\hline Components & $\begin{array}{c}\text { Sterilized Raw } \\
\text { CPW }\end{array}$ & $\begin{array}{c}\text { Sterilized Filtered } \\
\text { CPW }\end{array}$ & 25\% Filtered CPW & $\begin{array}{c}\text { H. pluvialis } \\
\text { Culture }\end{array}$ & $\begin{array}{c}\text { N. oleoabundans } \\
\text { Culture }\end{array}$ \\
\hline COD $\left(\mathrm{g} \cdot \mathrm{L}^{-1}\right)$ & $46.84 \pm 0.29$ & $32.78 \pm 0.20$ & $8.19 \pm 0.05$ & $3.21 \pm 0.03$ & $2.52 \pm 0.05$ \\
BOD $\left(\mathrm{g} \cdot \mathrm{L}^{-1}\right)$ & $16.89 \pm 0.10$ & $14.41 \pm 0.08$ & $3.60 \pm 0.02$ & $0.42 \pm 0.02$ & $0.34 \pm 0.01$ \\
BOD/COD ratio & $0.36 \pm 0.004$ & $0.44 \pm 0.005$ & $0.44 \pm 0.005$ & $0.13 \pm 0.01$ & $0.13 \pm 0.007$ \\
\hline
\end{tabular}

The COD and BOD removal efficiencies in the H. pluvialis culture were $60.80 \pm 0.34 \%$ and $88.32 \pm 0.69 \%$, respectively, and in the N. oleoabundans culture were $69.16 \pm 0.60 \%$ and $90.56 \pm 0.39 \%$, respectively, indicating that both microalgae efficiently used organic carbon as a source of energy and substrate for cell growth.

The low BOD/COD ratio (0.13) obtained at the end of both cultures indicates the presence of organic products resistant to biodegradation or products toxic to microorganisms in the final liquid residue.

Previous wastewater treatment studies by different microalgae species report COD removal varying from 55.4 to $90.8 \%[6,22,44]$. This study reports a satisfactory removal by both tested microalgae considering that the culture aeration did not influence the results. It was purposely not provided to avoid false results of COD and BOD reduction by introducing oxygen that contributes to the organic matter oxidation [22]. 


\subsection{Lipid Content}

The lipid contents (percentage dry weight $=\% \mathrm{dw}$ ) of $H$. pluvialis and N. oleoabundans grown on the CPW medium and synthetic mixotrophic medium were analyzed using samples obtained at the end of the experiments. The corresponding results are shown in Table 6. Considering the lipid production, an analysis of variance showed no significant difference $(p$-value $=0.142)$ between the synthetic mixotrophic medium and CPW medium.

Table 6. Total lipid content (\% dw) and lipid productivity $\left(\mathrm{g} \cdot \mathrm{L}^{-1} \cdot \mathrm{day}^{-1}\right)$ in H. pluvialis and N. oleoabundans, cultured in the synthetic mixotrophic medium and $25 \% \mathrm{CPW}$ medium. Values are the mean \pm standard error of three replicates.

\begin{tabular}{|c|c|c|c|c|}
\hline \multirow{2}{*}{$\begin{array}{l}\text { Microalgae } \\
\text { Species }\end{array}$} & \multicolumn{2}{|c|}{ Synthetic Mixotrophic Medium } & \multicolumn{2}{|c|}{ 25\% CPW Medium } \\
\hline & Lipids (\% dw) & $\begin{array}{l}\text { Lipid Productivity } \\
\left(\mathrm{g} \cdot \mathrm{L}^{-1} \cdot \mathrm{day}^{-1}\right)\end{array}$ & Lipids (\% dw) & $\begin{array}{l}\text { Lipid Productivity } \\
\left(\mathrm{g} \cdot \mathrm{L}^{-1} \cdot \text { day }^{-1}\right)\end{array}$ \\
\hline H. pluvialis & $18.5 \pm 0.71$ & $0.017 \pm 0.001$ & $15.2 \pm 1.06$ & $0.019 \pm 0.001$ \\
\hline N. oleoabundans & $21.0 \pm 1.41$ & $0.036 \pm 0.002$ & $19.2 \pm 1.13$ & $0.042 \pm 0.002$ \\
\hline
\end{tabular}

The results agree with the other reports that do not use physical or chemical stressing strategies to increase lipid production $[31,48]$ and suggest a convenient way to reduce the cost of algal lipids.

\subsection{Fatty Acid Composition of Biodiesel Produced from Microbial Lipids}

Table 7 shows the fatty acid composition of the lipid fraction extracted from each microalgae culture, determined using GC after conversion to fatty acid methyl esters. The estimated average conversion was $89.8 \pm 2 \%$.

Table 7. Major fatty acid profile (percentage of total fatty acids) from microalgae culture after transesterification. Values are the mean of three replicates $(n=3)$. SFA: Saturated fatty acids; MUFA: Monounsaturated fatty acids; PUFA: Polyunsaturated fatty acids; nd: Not detected.

\begin{tabular}{|c|c|c|c|c|}
\hline \multirow{2}{*}{ Fatty Acids } & \multicolumn{2}{|c|}{ H. pluvialis } & \multicolumn{2}{|c|}{ N. oleoabundans } \\
\hline & $\begin{array}{c}\text { Synthetic Mixotrophic } \\
\text { Medium }\end{array}$ & 25\% CPW Medium & $\begin{array}{c}\text { Synthetic Mixotrophic } \\
\text { Medium }\end{array}$ & 25\% CPW Medium \\
\hline C14:0-Miristic acid (\%) & $0.80 \pm 0.02$ & $0.8 \pm 0.03$ & $1.1 \pm 0.02$ & $0.97 \pm 0.07$ \\
\hline C16:0_Palmitic acid (\%) & $21.60 \pm 0.40$ & $21.23 \pm 0.31$ & $21.10 \pm 0.46$ & $21.77 \pm 0.32$ \\
\hline C16:1 Palmitoleic acid (\%) & $0.51 \pm 0.02$ & $0.50 \pm 0.02$ & $1.81 \pm 0.04$ & $1.80 \pm 0.02$ \\
\hline $\mathrm{C} 16: 2,3,4(\%)$ & $2.57 \pm 0.21$ & $2.33 \pm 0.21$ & $9.40 \pm 0.08$ & $9.32 \pm 0.07$ \\
\hline C18:0-Stearic acid (\%) & $4.50 \pm 0.50$ & $4.42 \pm 0.09$ & $6.03 \pm 0.40$ & $6.02 \pm 0.28$ \\
\hline C18:1-Oleic acid (\%) & $16.03 \pm 0.32$ & $16.13 \pm 0.35$ & $20.30 \pm 0.53$ & $20.33 \pm 0.24$ \\
\hline C18:2-Linoleic acid (\%) & $29.87 \pm 0.80$ & $29.80 \pm 0.72$ & $12.97 \pm 0.61$ & $13.28 \pm 0.33$ \\
\hline C18:3-Linolenic acid (\%) & $17.40 \pm 0.20$ & $17.53 \pm 0.12$ & $15.65 \pm 0.10$ & $15.65 \pm 0.11$ \\
\hline C20:0-Arachidic acid (\%) & $0.35 \pm 0.02$ & $0.35 \pm 0.01$ & nd & nd \\
\hline C20:4n6-Arachidonic acid (\%) & $1.18 \pm 0.04$ & $1.18 \pm 0.02$ & nd & nd \\
\hline Total $(\%)$ & $94.80 \pm 1.40$ & $94.29 \pm 0.80$ & $88.36 \pm 1.28$ & $89.13 \pm 0.78$ \\
\hline SFA $(\%) *$ & $27.25 \pm 0.90$ & $26.80 \pm 0.36$ & $28.24 \pm 0.84$ & $28.75 \pm 0.30$ \\
\hline MUFA (\%) * & $16.54 \pm 0.30$ & $16.64 \pm 0.34$ & $22.11 \pm 0.53$ & $22.13 \pm 0.25$ \\
\hline PUFA $(\%) *$ & $51.02 \pm 0.77$ & $50.85 \pm 0.69$ & $38.02 \pm 0.62$ & $38.25 \pm 0.30$ \\
\hline
\end{tabular}

* Percentage calculated based on the total known fatty acids; nd: Not detected. SFA, MUFA and PUFA stand for saturated, monounsaturated, and polyunsaturated totals, respectively.

The profiles of fatty acids in the microalgal lipids were similar after cultivation in CPW medium compared with a synthetic mixotrophic medium, and no significant differences $(p>0.05)$ were found between the cultures. Both microalgal oils were dominated by the presence of saturated fatty acid C16:0 (palmitic acid) and the mono and polyunsaturated fatty acids C18:1 (oleic acid), C18:2 (linoleic acid), and C18:3 (linolenic acid). The predominant lipid classes and content agree with the previous observations for $H$. pluvialis accumulating about 16\% lipids [38,49] and N. oleoabundans accumulating 15 to $36 \%$ lipids $[50,51]$ when cultivated without a starvation phase and producing primarily unsaturated fatty acids. 
The microalgae H. pluvialis and N. oleoabundans offer an advantage in biodiesel application since they have been related to the formation of carotenoids in the lipid bodies $[52,53]$ under certain growth conditions. The stress conditions at the end of culture or longer cultivations could be a strategy to reduce the oxidation of microalgae lipids.

\title{
4. Conclusions
}

To conclude, microalgae cultivation on cassava processing wastewater could be economically valuable for the production of biomass rich in lipids. Despite the variations in its composition, cassava wastewater remains a viable alternative for use as a microalgae medium without any supplementation, including the cultivation of $H$. pluvialis and $N$. oleoabundans.

The result of this study shows that microalgae strains H. pluvialis and N. oleoabundans are not only capable of growing in a CPW-based medium, but they are also agents for the mitigation of pollutant load improving the water quality, including BOD, COD, nitrate, and phosphate reduction. In addition, they can be used as a potential pathway for biofuel production. In the CPW culture, the microalgae grew faster, and the lipid production was similar to the synthetic mixotrophic cultures.

Regression models showed that the diluted CPW can sustain a larger production of biomass, but requires more land area for cultivation in ponds or raceways. While the treatment can be achieved with higher CPW concentrations and less production area, but leads to a lower biomass production overall. Therefore, an evaluation of the processing conditions, similar to that used in this research must be done in a species-based approach.

\begin{abstract}
Author Contributions: Main experimental investigation, analysis, writing, V.G.S.; conceptualization, revision, funding, C.R.S.; writing, analyses, D.T.M.-A.; writing, revision, M.A.d.C.; writing, analyses, revision, G.V.d.M.P.; conceptualization, project management, revision, J.C.d.C. All authors have read and agreed to the published version of the manuscript.
\end{abstract}

Funding: This work was supported by $\mathrm{CNPq}$, the Brazilian National Council for Scientific and Technological Development, grant numbers 407543/2013-0 and 314147/2018-7, and CAPES, the Coordination of Improvement of Higher Education Personnel-PROEX program.

Institutional Review Board Statement: Not applicable.

Informed Consent Statement: Not applicable.

Data Availability Statement: Data sharing not applicable.

Conflicts of Interest: The authors declare no conflict of interest.

\section{References}

1. Perez-Garcia, O.; Escalante, F.M.E.; De-Bashan, L.E.; Bashan, Y. Heterotrophic cultures of microalgae: Metabolism and potential products. Water Res. 2011, 45, 11-36. [CrossRef]

2. Bhatnagar, A.; Bhatnagar, M.; Chinnasamy, S.; Das, K.C. Chlorella minutissima-A Promising Fuel Alga for Cultivation in Municipal Wastewaters. Appl. Biochem. Biotechnol. 2009, 161, 523-536. [CrossRef]

3. Neves, C.; Maroneze, M.; Dos Santos, A.M.; Francisco, E.C.; Wagner, R.; Zepka, L.Q.; Jacob-Lopes, E. Cassava processing wastewater as a platform for third generation biodiesel production. Sci. Agricol. 2016, 73, 412-416. [CrossRef]

4. De Carvalho, J.C.; Sydney, E.B.; Tessari, L.F.A.; Soccol, C.R. Chapter 2-Culture media for mass production of microalgae. In Biomass, Biofuels, Biochemicals: Biofuels from Algae, 2nd ed.; Pandey, A., Chang, J.S., Soccol, C.R., Lee, D.J., Chisti, Y., Eds.; Elsevier: Amsterdam, The Netherlands, 2019; pp. 33-50. [CrossRef]

5. Leano, E.; Babel, S. Effects of pretreatment methods on cassava wastewater for biohydrogen production optimization. Renew. Energy 2012, 39, 339-346. [CrossRef]

6. Hongyang, S.; Yalei, Z.; Chunmin, Z.; Xuefei, Z.; Jinpeng, L. Cultivation of Chlorella pyrenoidosa in soybean processing wastewater. Bioresour. Technol. 2011, 102, 9884-9890. [CrossRef]

7. Wu, L.F.; Chen, P.C.; Huang, A.P.; Lee, C.M. The feasibility of biodiesel production by microalgae using industrial wastewater. Bioresour. Technol. 2012, 113, 14-18. [CrossRef]

8. de Carvalho, J.C.; Borghetti, I.A.; Cartas, L.C.; Woiciechowski, A.L.; Soccol, V.T.; Soccol, C.R. Biorefinery integration of microalgae production into cassava processing industry: Potential and perspectives. Bioresour. Technol. 2018, 247, 1165-1172. [CrossRef]

9. FAOSTAT-Database; Food and Agriculture Organization of the United Nations: Rome, Italy, 2020. 
10. Martinez-Burgos, W.J.; Sydney, E.B.; Medeiros, A.B.P.; Magalhães, A.I.; de Carvalho, J.C.; Karp, S.G.; Vandenberghe, L.P.D.S.; Letti, L.A.J.; Soccol, V.T.; Pereira, G.V.D.M.; et al. Agro-industrial wastewater in a circular economy: Characteristics, impacts and applications for bioenergy and biochemicals. Bioresour. Technol. 2021, 341, 125795. [CrossRef]

11. Setyawaty, R.; Katayama-Hirayama, K.; Kaneko, H.; Hirayama, K. Current tapioca starch wastewater (TSW) management in Indonesia. World Appl. Sci. J. 2011, 14, 658-665.

12. Cartas, L.C. Isolamento e Cultivo de Microalgas em Resíduo Líquido do Processamento da Mandioca: Manipueira; Federal University of Tocantins: Palmas, Brasil, 2017.

13. Reungsang, A.; Sangyoka, S.; Imai, T.; Chaiprasert, P. Biohydrogen Production from Cassava Starch Manufacturing Wastewater. Asian J. Energy Environ. 2006, 7, 367-377.

14. Maróstica, M.R., Jr.; Pastore, G.M. Production of R-(+)- $\alpha$-terpineol by the biotransformation of limonene from orange essential oil, using cassava waste water as medium. Food Chem. 2007, 101, 345-350. [CrossRef]

15. Costa, S.G.; Nitschke, M.; Lépine, F.; Déziel, E.; Contiero, J. Structure, properties and applications of rhamnolipids produced by Pseudomonas aeruginosa L2-1 from cassava wastewater. Process Biochem. 2010, 45, 1511-1516. [CrossRef]

16. Cappelletti, B.M.; Reginatto, V.; Amante, E.R.; Antônio, R.V. Fermentative production of hydrogen from cassava processing wastewater by Clostridium acetobutylicum. Renew. Energy 2011, 36, 3367-3372. [CrossRef]

17. Martinez-Burgos, W.J.; Sydney, E.B.; Brar, S.K.; Tanobe, V.O.D.A.; Medeiros, A.B.P.; de Carvalho, J.C.; Soccol, C.R. The effect of hydrolysis and sterilization in biohydrogen production from cassava processing wastewater medium using anaerobic bacterial consortia. Int. J. Hydrogen Energy 2019, 44, 25551-25564. [CrossRef]

18. de Faria Ferreira Carraro, C.; Loures, C.C.A.; de Castro, J.A. Microalgae Technique for Bioremediation Treatment of Cassava Wastewater. Water Air Soil Pollut. 2021, 232, 281. [CrossRef]

19. Coutinho Rodrigues, O.H.; Itokazu, A.G.; Rörig, L.; Maraschin, M.; Corrêa, R.G.; Pimentel-Almeida, W. Evaluation of astaxanthin biosynthesis by Haematococcus pluvialis grown in culture medium added of cassava wastewater. Int. Biodeterior. Biodegrad. 2021, 163, 105269. Available online: https:/ /www.sciencedirect.com/science/article/pii/S0964830521000998 (accessed on 10 October 2021). [CrossRef]

20. Okpozu, O.O.; Ogbonna, I.O.; Ikwebe, J.; Ogbonna, J.C. Phycoremediation of cassava wastewater by Desmodesmus armatus and the concomitant accumulation of lipids for biodiesel production. Bioresour. Technol. Rep. 2019, 7, 100255. [CrossRef]

21. Araujo, G.S.; Santiago, C.S.; Moreira, R.T.; Neto, M.P.D.; Fernandes, F.A. Nutrient removal by Arthrospira platensis cyanobacteria in cassava processing wastewater. J. Water Process. Eng. 2020, 40, 101826. [CrossRef]

22. Mata, T.M.; Melo, A.C.; Simões, M.; Caetano, N. Parametric study of a brewery effluent treatment by microalgae Scenedesmus obliquus. Bioresour. Technol. 2012, 107, 151-158. [CrossRef]

23. Abdel-Raouf, N.; Al-Homaidan, A.A.; Ibraheem, I.B.M. Microalgae and wastewater treatment. Saudi J. Biol. Sci. 2012, 19, 257-275. Available online: http:/ / www.scopus.com/inward/record.url?eid=2-s2.0-84863199246\&partnerID=tZOtx3y1 (accessed on 14 July 2014). [CrossRef]

24. Larissa, B.; Maran, R.M.; Ioan, B.; Anca, N.; Mircea-Iosif, R.; Horia, T.; Gheorghe, F.; Speranta, M.E.; Dan, M.I. Adjusted Net Savings of CEE and Baltic Nations in the Context of Sustainable Economic Growth: A Panel Data Analysis. J. Risk Financ. Manag. 2020, 13, 234. [CrossRef]

25. Colusse, G.A.; Duarte, M.E.R.; de Carvalho, J.C.; Noseda, M.D. Media effects on laboratory scale production costs of Haematococcus pluvialis biomass. Bioresour. Technol. Rep. 2019, 7, 100236. [CrossRef]

26. Wei, A.; Zhang, X.; Wei, D.; Chen, G.; Wu, Q.; Yang, S.-T. Effects of cassava starch hydrolysate on cell growth and lipid accumulation of the heterotrophic microalgae Chlorella protothecoides. J. Ind. Microbiol. Biotechnol. 2009, 36, $1383-1389$. [CrossRef]

27. Lu, Y.; Zhai, Y.; Liu, M.; Wu, Q. Biodiesel production from algal oil using cassava (Manihot esculenta Crantz) as feedstock. Environ. Boil. Fishes 2009, 22, 573-578. [CrossRef]

28. Rismani-Yazdi, H.; Haznedaroglu, B.Z.; Hsin, C.; Peccia, J. Transcriptomic analysis of the oleaginous microalga Neochloris oleoabundans reveals metabolic insights into triacylglyceride accumulation. Biotechnol. Biofuels 2012, 5, 74. [CrossRef]

29. Francisco, C.; Franco, T.T.; Wagner, R.; Jacob-Lopes, E. Assessment of different carbohydrates as exogenous carbon source in cultivation of cyanobacteria. Bioprocess Biosyst. Eng. 2014, 37, 1497-1505. [CrossRef] [PubMed]

30. Sun, L.; Wan, S.; Yu, Z.; Wang, Y.; Wang, S. Anaerobic biological treatment of high strength cassava starch wastewater in a new type up-flow multistage anaerobic reactor. Bioresour. Technol. 2011, 104, 280-288. [CrossRef]

31. Popovich, C.A.; Damiani, C.; Constenla, D.; Martínez, A.M.; Freije, H.; Giovanardi, M.; Pancaldi, S.; Leonardi, P.I. Neochloris oleoabundans grown in enriched natural seawater for biodiesel feedstock: Evaluation of its growth and biochemical composition. Bioresour. Technol. 2012, 114, 287-293. [CrossRef]

32. Andrew, D.E.; Lenore, S.C.; Eugene, W.R.; Arnold, E.G. Standard methods for the examination of water and wastewater, 21st edition. Am. Public Health Assoc. Wash. DC 2005. Available online: https://beta-static.fishersci.com/content/dam/fishersci/en_US/ documents / programs/scientific/technical-documents/white-papers/apha-water-testing-standard-methods-introductionwhite-paper.pdf (accessed on 8 October 2021).

33. Daniels, L.; Hanson, R.S.; Philips, J.A. Chemical Analysis in Methods for General and Molecular Bacteriology; American Society for Microbiology: Washington, DC, USA, 1994; pp. 512-554. 
34. Nelson, N. A photometric adaptation of the Somogyi method for the determination of glucose. J. Biol. Chem. 1944, 153, 375-380. [CrossRef]

35. U.S. Environmental Protection Agency U-E. Total, Fixed, and Volatile Solids in Water, Solids and Biosolids; Method 1684; EPA-821-R01-015; U.S. Environmental Protection Agency UE: Copenhagen, Denmark, 2001.

36. Folch, J.; Lees, M.; Sloane Stanley, G.H. A simple method for the isolation and purification of total lipides from animal tissues. J. Biol. Chem. 1957, 226, 497-509. [CrossRef]

37. Liu, B.; Zhao, Z. Biodiesel production by direct methanolysis of oleaginous microbial biomass. J. Chem. Technol. Biotechnol. 2007, 82, 775-780. [CrossRef]

38. Damiani, M.C.; Popovich, C.A.; Constenla, D.; Leonardi, P.I. Lipid analysis in Haematococcus pluvialis to assess its potential use as a biodiesel feedstock. Bioresour. Technol. 2010, 101, 3801-3807. [CrossRef]

39. Pruvost, J.; Van Vooren, G.; Cogne, G.; Legrand, J. Investigation of biomass and lipids production with Neochloris oleoabundans in photobioreactor. Bioresour. Technol. 2009, 100, 5988-5995. [CrossRef] [PubMed]

40. Templeton, D.; Laurens, L.M. Nitrogen-to-protein conversion factors revisited for applications of microalgal biomass conversion to food, feed and fuel. Algal Res. 2015, 11, 359-367. [CrossRef]

41. de Carvalho, J.C.; Magalhães, A.I.; de Melo Pereira, G.V.; Medeiros, A.B.P.; Sydney, E.B.; Rodrigues, C. Microalgal biomass pretreatment for integrated processing into biofuels, food, and feed. Bioresour. Technol. 2020, 300, 122719. Available online: https:/ / www.sciencedirect.com/science/article/pii/S0960852419319480?via\%3Dihub (accessed on 24 January 2020). [CrossRef]

42. Geider, R.; La Roche, J.; Geider, R.J. European Journal of Phycology Redfield revisited: Variability of C:N:P in marine microalgae and its biochemical basis Redfield revisited: Variability of C: N: P in marine microalgae and its biochemical basis. Eur. J. Phycol. Br. Phycol. Soc. 2002, 371, 1-17.

43. Ruiz González, J.; Álvarez Díaz, P.D.; Arbib, Z.; Garrido Pérez, C.; Barragán Sánchez, J.; Perales Vargas-Machuca, J.A. Effect of Nitrogen and Phosphorus Concentration on Their Removal Kinetic in Treated Urban Wastewater by Chlorella Vulgaris. Int. J. Phytoremediation 2011, 13, 884-896. [CrossRef]

44. Wang, H.; Xiong, H.; Hui, Z.; Zeng, X. Mixotrophic cultivation of Chlorella pyrenoidosa with diluted primary piggery wastewater to produce lipids. Bioresour. Technol. 2012, 104, 215-220. [CrossRef]

45. Aslan, S.; Kapdan, I.K. Batch kinetics of nitrogen and phosphorus removal from synthetic wastewater by algae. Ecol. Eng. 2006, 28, 64-70. [CrossRef]

46. Karthikeyan, S.; Prathima, A. Neochloris oleoabundans microalgae oil as a fuel for diesel engines. Energy Sources Part A Recover Util. Environ. Eff. 2017, 39, 606-612. [CrossRef]

47. Samudro, G.; Mangkoedihardjo, S. Review on Bod, Cod and Bod/Cod Ratio: A Triangle Zone for Toxic, Biodegradable and Stable Levels. Int. J. Acad. Res. 2010, 2, 4.

48. Lei, A.; Chen, H.; Shen, G.; Hu, Z.; Chen, L.; Wang, J. Expression of fatty acid synthesis genes and fatty acid accumulation in haematococcus pluvialis under different stressors. Biotechnol. Biofuels 2012, 5, 18. [CrossRef] [PubMed]

49. Liu, P.; Corilo, Y.; Marshall, A.G. Polar Lipid Composition of Biodiesel Algae Candidates Nannochloropsis oculata and Haematococcus pluvialis from Nano Liquid Chromatography Coupled with Negative Electrospray Ionization 14.5 T Fourier Transform Ion Cyclotron Resonance Mass Spectrometry. Energy Fuels 2016, 30, 8270-8276. [CrossRef]

50. Abu Hajar, H.A.; Riefler, R.G.; Stuart, B.J. Cultivation of the microalga Neochloris oleoabundans for biofuels production and other industrial applications (a review). Appl. Biochem. Microbiol. 2017, 53, 640-653. [CrossRef]

51. Günerken, E.; D’Hondt, E.; Eppink, M.; Elst, K.; Wijffels, R. Influence of nitrogen depletion in the growth of N. oleoabundans on the release of cellular components after beadmilling. Bioresour. Technol. 2016, 214, 89-95. [CrossRef]

52. Goiris, K.; Muylaert, K.; Fraeye, I.; Foubert, I.; De Brabanter, J.; De Cooman, L. Antioxidant potential of microalgae in relation to their phenolic and carotenoid content. J. Appl. Phycol. 2012, 24, 1477-1486. [CrossRef]

53. Castro-Puyana, M.; Herrero, M.; Urreta, I.; Mendiola, J.A.; Cifuentes, A.; Ibáñez, E.; Suárez-Alvarez, S. Optimization of clean extraction methods to isolate carotenoids from the microalga Neochloris oleoabundans and subsequent chemical characterization using liquid chromatography tandem mass spectrometry. Anal. Bioanal. Chem. 2013, 405, 4607-4616. [CrossRef] 